\title{
ФОРМИРОВАНИЕ КОМПЕТЕНЦИИ ПЛАНИРОВАНИЯ КАРЬЕРЫ В КОНТЕКСТЕ РЕПРЕЗЕНТАЦИИ ОБРАЗА БУДУЩЕГО
}

\author{
Конюхова Татьяна Васильевна ${ }^{1}$, \\ konykhova@tpu.ru \\ Конюхова Екатерина Тимофеевна ${ }^{2}$, \\ konjuhova50@mail.ru \\ Гончаренко Марк Васильевич1, \\ markgon73@tpu.ru
}
${ }^{1}$ Национальный исследовательский Томский политехнический университет, Россия, 634050, Томск, пр. Ленина, 30
2 Новокузнецкий институт (филиал) Кемеровский государственный университет, Россия, 654027, Новокузнецк, ул. Циолковского, 23

\begin{abstract}
Конюхова Татьяна Васильевна, кандидат философских наук, доцент отделения социальногуманитарных наук Школы базовой инженерной подготовки Национального исследовательского Томского политехнического университета.
\end{abstract}

Конюхова Екатерина Тимофеевна, кандидат педагогических наук, доцент кафедры психологии и общей педагогики Новокузнецкого института (филиала) Кемеровского государственного университета.

Гончаренко Марк Васильевич, доктор философских наук, доцент отделения социальногуманитарных наук Школы базовой инженерной подготовки Национального исследовательского Томского политехнического университета.

В работе рассматривается проблематика карьерного планирования, позволяющего личности стимулировать себя для организации и реализации успешных социально-трудовых отношений. В современном контексте планирование карьеры является одним из аспектов благополучия, выстраивания образа будущего и его репрезентации. Компетенция планирования карьеры формируется с учетом ресурсных возможностей социально-психологического капитала личности студента. Карьерная компетентность строится на способности человека осознавать возможности своего карьерного потенциала и использовать их в развитии собственной карьеры, уметь преодолевать препятствия и затруднения с целью оптимизации карьерного продвижения. Цель: разработать рекомендации формирования профессиональной компетенции карьерного планирования студентом в образовательном пространстве вуза. Методы: сравнительный и статистический анализ эмпирических данных, полученных в результате диагностического исследования. Диагностический инструментарий включал: метод ранжирования признаков понятия «карьера»; опросники «Индекс жизненной удовлетворенности» (адаптация Н.В. Паниной), ДДо (Е.А. Климов); методику удовлетворенности основных потребностей (А. Маслоу); социально-психологические установки (О.Ф. Потемкина); жизнестойкость (С. Мадди); Шкалу субъективного благополучия; Шкалу психологического благополучия (К. Рифф); способность к самоуправлению (Н.М. Пейсахов); МПД (К. Замфир в модификации А. Реана). Обработка проводилась с применением статистического пакета программ для социальных наук SPSS 22.0. Результаты: сформулировано понятие компетенции карьерного планирования и описана его роль в репрезентации будущего; проведено исследование структурных составляющих формирования планирования образа карьеры будущими специалистами, на основании которых составлен социально-психологический портрет студента с высоким, средним, низким уровнем выраженности показателей. Описана рекомендация возможной стратегии вы- 
страивания работы вуза по формированию компетенции планирования карьеры студента через развитие параметров социально-личностных характеристик студента и его социальнопсихологического капитала, включая некоторые конкретные формы работы.

Ключевые слова: Карьера, компетенция, карьерное планирование, конструирование карьеры, репрезентация образа будущего, социально-психологический капитал.

Планирование достижения человеком успешности и реализации намеченных целей в различных сферах деятельности является одним из важнейших этапов формирования представлений образа собственного будущего как «образа для себя» и адекватной оценки собственного адаптационного ресурса $[1,2,3]$. Карьерное планирование рассматривается как значимая компетенция и технология, позволяющая сотруднику стимулировать себя для организации и реализации успешных социально-трудовых отношений. Данная компетенция базируется на социально-личностном человеческом капитале, который, согласно Концепции долгосрочного социально-экономического развития РФ [4], необходимо формировать для обеспечения роста инновационной экономики страны. Позитивное карьерное планирование, наряду с другими факторами, определяет репрезентацию образа будущего конкретного человека и образа будущего страны в целом. Карьерная компетентность строится на способности человека осознавать возможности своего карьерного потенциала, использовать в развитии собственной карьеры, уметь преодолевать препятствия и затруднения с целью оптимизации карьерного продвижения.

Базой для формирования компетенции карьерного планирования может выступать вуз, поскольку в студенческой среде традиционно происходит профессиональное самоопределение человека. Помимо получения теоретической подготовки студент начинает планировать свою профессиональную деятельность и выстраивать траекторию карьерного роста. Ряд исследований подтверждают, что образовательная среда имеет достаточно сильную положительную связь с карьерной мотивацией и последующей адаптивностью в профессиональной сфере [5].

Именно на данном этапе следует активно помогать в формировании компетенции карьерного планирования, которое неразрывно связано с развитием и обогащением социально-психологического капитала личности и ее индивидуально-психологических особенностей. Данную работу необходимо начинать с первого курса, потому что при всей противоречивости профессионального выбора, студенту потребуется умение выстраивать эффективные стратегии и тактики карьеры с опорой на свой ресурс. Исследования показывают, что при проведении целенаправленной работы в данном направлении адаптивность молодых людей к карьере возрастает [6]. Кроме того, данное умение будет зависеть от потребностно-мотивационных устремлений, установки на успешность карьерно-профессионального развития, представлений своего профессионального и личностного будущего, уровня профессиональных знаний, возможностей человека.

Для формирования компетенции карьерного планирования и обеспечения качества образования вуз проводит анализ требований рынка труда региона и страны, запросов и ожиданий студентов, координирует работу в этом направлении. В период обучения вуз предоставляет студенту возможность получить знания в области своей профессиональной деятельности, научиться ориентироваться на рынке труда ближайшего будущего, анализировать спрос на рабочую силу, формирует способности к обучению и самообучению, взаимодействию в группе, проектированию профессионального продвижения и т. п. Несмотря на реализуемую вузом комплексную работу, только треть 
студентов сегодня оценивает свои возможности как достаточные для того, чтобы стать успешным в профессии и в жизни. Иными словами, позитивный индивидуальный образ своего будущего и образ будущего страны среди студентов не сформирован в должной мере. Более того, сегодня у молодых людей наблюдается представление о будущем, «которое радикально отрывается от настоящего» и представляет некий отдельный хронотоп [7]. Отсюда появляется вопрос о том, что же может и должен сделать вуз со своей стороны, чтобы изменить данную ситуацию и сформировать у студента достаточную компетенцию планирования карьеры, самореализации, обогащения социальнопсихологического капитала будущего специалиста и образа будущего?

В разные исторические периоды понимание карьеры соотносилось с понятиями образа жизни, способа мышления, стратегии самореализации. В социальных науках сегодня используются такие синонимичные понятию «карьера» термины, как профессиональный жизненный путь, профдеятельность, социальный лифт, профобразование и др. $[8,9]$. Карьера касается делового статуса, личности субъекта, характера продвижения к трудовому будущему, самовыражения и удовлетворения трудом [10], обеспечения качества жизни, жизнестойкости, субъективно-личностного благополучия [11]. Критериями успешной карьеры для личности становятся удовлетворенность жизненной ситуацией (субъективный критерий) и социально-профессиональный успех (объективный критерий). Таким образом, по своей сути карьера представляет собой сложное социально-психологическое явление, охватывающее все сферы жизни человека, продвижения и достижения успеха при рациональном использовании накопленного капитала.

Планирование профессиональной карьеры представляет собой сложный процесс осознания студентом представлений о профессии, образа планируемого и конкретных стратегий профессионального будущего, оценки субъективно значимых потребностей, готовности, анализа ресурсов, ограничений, контроля, корректировки целей достижения профессиональных перспектив. Сдерживать формирование данной компетенции в ходе подготовки специалиста может недостаток знаний студента по психологии личности, отсутствие условий социально-образовательного пространства, недооценка администрации вуза значимости этой сферы для успешной социализации выпускников.

Предлагаем рассматривать целенаправленную работу вуза и его отдельных структурных подразделений (например, Центр содействия трудоустройству и развития карьеры (Томск, НИ ТПУ), учебно-консультационный методический центр содействия трудоустройству выпускников «Карьера» (Новокузнецк, СибГИУ), отдел профориентации, дополнительного образования и развития карьеры (Новокузнецк, НФИ КемГУ)) как стратегию формирования компетенции карьерного планирования, организацию взаимодействия с базовыми предприятиями, формирование доминантных признаков профессиональной компетентности, активность студентов в направлении профессионально-личностного роста. Подобная деятельность реализуется одновременно с формированием и/или наращиванием социально-психологического капитала личности и профилактирует социально-профессиональную дезадаптацию. Исследования показывают, что наличие куратора, тьютора и/или наставника положительно влияет на саморефлексию студента, планирование им карьерного вектора и адаптацию в профессиональной сфере $[12,13]$.

Для выработки рекомендаций по повышению эффективности работы вуза в части формирования указанной компетенции подлежат изучению условия формирования «поля продуктивности» будущей карьеры студентов, маркеры социальнопсихологического капитала и благополучия студента в условиях профессиональной подготовки. Это связано с тем, что, формируя будущий карьерный вектор, человек про- 
являет естественное желание и стремление реализовать социально-личностный и профессиональный потенциал, стремится обеспечить условия встраивания в жизнь, профессию, социум.

Интервьюируя в начале 2019 г. студентов 1-2 курса одного из сибирских вузов, мы выявили, что они понимают профессиональную карьеру как «повышение статуса человека в обществе» $(55,3 \%)$, «профессиональный рост» $(31,7 \%)$, «движение по служебной лестнице» (36,6 \%), «личные достижения человека в профессии» $(32,7$ \%), карьерный рост сравнивают с увеличением материальных выгод $(62,1 \%)$, а не с самосовершенствованием, самореализацией в профессиональной деятельности.

Опрос рекрутингового портала HeadHunter и сайта для молодых специалистов Career.ru [14] показал, что из 533 студентов и молодых специалистов Кемеровской области 53 \% респондентов мечтают о собственном деле, своей компании. Добиться признания на рынке труда как высококвалифицированного специалиста желают треть респондентов. Каждый четвёртый студент и молодой специалист видит себя в будущем руководителем компании. Назначение на руководящую должность является следствием признания профессионализма сотрудника (65 \%), желание стать директором (48 \%) связано с ожиданием получения высокого оклада [15]. Пройти по карьерной лестнице до должности директора респонденты предполагают в среднем за 5 лет 66 \% респондентов, выбирая между должностью и зарплатой, предпочли бы высокую зарплату, а не должность.

Опрос в конце 2018 года 80 студентов 3-го курса вузов юга Кузбасса показывал, что 70 \% студентов выделяют доминантным денежный заработок, 69 \% студентов считают, что профессиональная карьера - это достижение высокого дохода, социального статуса, тем самым, планируя будущую карьеру, они придают значение социальному престижу и стремлению к продвижению по службе. $18 \%$ студентов считают, что эффективное планирование профессиональной карьеры потребует приобретения знаний, сверх того, что определено программами обучения в вузе. Полученные знания должны сочетаться с «профессиональной мобильностью», «адаптивностью», «практической ориентированностью», возможностью принести пользу обществу, профессионально и личностно развиваться, постепенно накапливать опыт.

В целом современный студент эгоцентрично планирует личный успех в профессии, не стремится учитывать риски и планировать запасные варианты карьерного роста. Изучая аспекты планирования карьеры студентом в образовательном поле вуза, отмечаем, что студенты недостаточно информированы о ситуации на региональных рынках труда, идеализируют представления о будущей работе при выборе профессии, практически не владеют современными технологиями трудоустройства, оценкой шансов социально-личностных возможностей на успешную карьеру. Осуществляя выбор будущей профессии, они часто не знают уровень своего социально-психологического ресурса планирования, управления карьерным ростом, осознания значимости профессионально-личностного благополучия в трудовой деятельности.

Считаем, что профессиональная карьера зависит от сформированных возможностей личности преобразовать особенности личностной сферы, приобретенные компетенции, навыки, которые формируют социально-психологический капитал будущего человека труда, социально-психологическое благополучие, качество жизни человека, а следовательно, определяют репрезентацию образа будущего личности. Карьера может строиться по вертикали и по горизонтали [16]. В большинстве своем возможность построить карьеру по горизонтали становится для человека наиболее приемлемым и желательным в достижении профессионализма. У такой карьеры нет «потолка», она фор- 
мируется под влиянием профессиональных целей, устремлений, временных возможностей человека, создает условия благополучия в труде и жизни. Высокоресурсному студенту - будущему специалисту, - нацеленному на профессиональное развитие, завоевание авторитета, перспективу и социально-психологическое благополучие в жизни спланировать и реализовать карьерный вектор будет легче. Иными словами, он обладает достаточным социально-психологическим капиталом для разумного карьерного планирования и профессионального будущего.

Введенное А.Н. Татарко понятие социально-психологический капитал личности, рассматриваемый как ресурс психологических отношений личности к различным аспектам социальной реальности, облегчает достижение поставленных целей [17-20]. В нашем случае это планирование и репрезентация своего будущего в разных сферах жизни [21], в т. ч. в трудовом процессе, карьере.

Исследования экспертов ФОМ о представлении россиян о будущем страны через 20 лет [22] показали, что доминирующими мотивами у населения, включая молодежь, являются: ориентация на материальные ценности, возросшее стремление к вознаграждению; необоснованные притязания, завышенная самооценка; отсутствие моральных ориентиров и др. Отношение к труду и мотивация работать ради денег, статуса, престижа, общения, удовлетворенности, самореализации определяется предыдущим опытом, преобладающими социальными установками и желаемым образом будущего. Это подтверждается приведенными выше числовыми показателями.

На развитие карьеры влияют ряд факторов, к числу которых мы относим особенности социально-экономической ситуации в обществе, мотивацию, самооценку, уровень притязаний, состояние здоровья, профессиональную готовность и др. Среди факторов, определяющих профессионально-личностное развитие индивида, доминантой является «профессиональная Я-концепция» с конативным, когнитивным, эмоциональным компонентами. Они включают набор характеристик о самовосприятии, представлении о себе как профессионале, субъекте профессиональной деятельности и личности. В «Я-концепции» интегрированы внутренняя мотивация, смысл и отношение к профессии, регуляция деятельности, взаимодействия в процессе труда, развития личности [23] и карьеры. Различные аспекты феномена «карьеры» рассматривали А.М. Рикель, О.А. Тихомандрицкая и ряд других авторов [16, 24 и др.]. Они пришли к выводу, что успешность человека в профессиональной деятельности зависит от положительной профессиональной Я-концепции.

Как показывают наблюдения, люди, при низкой самооценке возможностей, избегают незнакомых видов деятельности и ситуаций, при адекватности притязаний, уверенности, профессионального опыта оперируют разнообразными вариантами, стратегиями планирования карьеры. Полученные результаты исследования среди респондентов Центра содействия трудоустройству и развитию карьеры (Томск, ТПУ), Центра дополнительного образования «Планирование карьеры» (Томск), учебного консультативно-методического центра профориентации и содействия трудоустройству выпускников «Карьера» (Новокузнецк, СибГИУ), Отдела профориентации, дополнительного образования и развития карьеры (Новокузнецк, НФИ КемГУ) показывают, что у многих студентов имеется низкая степень владения технологиями трудоустройства, недостаток осведомленности о ситуации на региональных рынках труда, идеализированные представления о будущей работе, неготовность осознать и оценить свои способности, устремления, свое место на рынке труда. Кроме того, планирование карьеры затрудняется в силу несформированности компонентов социально-психологического капитала, а именно из-за низкого уровня внутренней мотивации, удовлетворенности основных по- 
требностей, жизнестойкости, субъективно-психологического благополучия, способности к самоуправлению, конструктивных социально-психологических установок выбора профессии и др.

С целью изучения психологических характеристик и структурных составляющих, влияющих на планирования образа карьеры будущими специалистами, нами было организовано исследование на выборке студентов ТПУ г. Томска, НФИ КемГУ и СибГИУ г. Новокузнецка. Выборку составили студенты 1-х и 4-х курсов, 108 человек, в возрасте от 17 до 21 года, 45 \% юношей и $55 \%$ девушек.

Программа исследования была построена на использовании метода ранжирования признаков понятия карьера; решения ситуаций; опросников: «Индекс жизненной удовлетворенности» (Life Satisfaction Index A, LSIA) (Bernice L. Neugarten) (адаптация Н.В. Паниной), ДДО (Е.А. Климов); методик: удовлетворенность основных потребностей (А. Маслоу); социально-психологические установки (О.Ф. Потемкина); Шкала субъективного благополучия; Шкала психологического благополучия (К. Рифф); способность к самоуправлению (Н.М. Пейсахов); МПД (К. Замфир в модификации А. Реана); жизнестойкость (С. Мадди); методов статистической обработки результатов в программе SPSS22 для Windows.

Метод определений показал, что среди доминантных признаков жизни современного человека карьера представлена с показателем ( $\mathrm{r}=0,53)$. Сюда же вошли материальное благополучие, профперспективы, престиж, профдеятельность, успешность, готовность, самореализации и др. В содержательном поле социально-психологических представлений о карьере незначительно представлены признаки личностной сферы: психологического благополучия $(\mathrm{r}=0,42)$, защищенности $(\mathrm{r}=0,4)$, потребность уважения, внутренняя мотивация, планирование, принятие решений по $(\mathrm{r}=0,47)$, установка на труд $(\mathrm{r}=0,46)$, самоконтроль, удовлетворенность повседневной жизнью $(\mathrm{r}=0,45)$. Выявленные особенности студентов не в полной мере соответствуют готовности планирования карьеры и конкурентоспособности выпускника вуза.

При анализе результатов диагностики содержания компонентной структуры ресурса социально-психологического капитала в условиях планирования будущей профессиональной карьеры был составлен обобщенный профиль студента с показателями трех уровней: высоким (19,8 \% студентов), средним $(44,1 \%)$ и низким $(35 \%)$.

Студент с высоким уровнем проявления интегрированных признаков социальнопсихологического капитала, представленных в содержании используемых методик, при планировании образа будущего и карьеры в ходе профессиональной подготовки, имеет четкие ориентиры на приобретение практического навыка взаимодействия с окружающим миром, нестандартный подход разрешения ситуаций, направленность на высокое качество жизни, социально-психологическое благополучие, мотивацию профессиональной деятельности. Решению этих вопросов способствует внешняя положительная мотивация (.62), автономия в форме баланса личностных и общественных интересов (.52), саморегуляция поведения (.64), планирование будущего (.71), осознание необходимости личностного роста и самопринятие, как способности формировать адекватный взгляд на социально-экономическую ситуацию развития общества и имеющийся собственный ресурс, стремление к самореализации (.57), умение создавать основу благополучия, в том числе, и материальную, в профессии и в жизни.

Доминирующие социально-психологические установки «на результат» (.67), свободу (.79.6), деньги (.62) обеспечивают субъекту личностный успех, успешность в деятельности, свободу в выборе способа достижения намеченного. Вовлеченность во взаимодействие с окружающим миром расширяет поле социально-психологической и 
профессиональной информированности, коммуникабельности, ощущение своей значимости в жизни и профессии. Субъективное благополучие студенты связывают с состоянием и сохранением своего здоровья (.69). Жизненную удовлетворенность создает положительная оценка себя и собственных поступков, уверенность в том, что в жизни и в карьере их ждет успех. Мотивационный комплекс студентов представлен высоким значением внешней положительной (4.8б.) и внутренней мотивации (4.0б.), что можно считать стремлением студента достичь в профессии определенных позитивных результатов.

Студенты с высоким уровнем социально-психологических компонентов планирования собственной карьеры актуализируют внутренние мотивы осознанной увлеченности деятельностью (.64.6), познавательного мотива для расширения сферы интересов к деятельности, возникающим сомнением обеспечить себе успех, но при этом мотив самоуважения (.69.8) ориентирует студентов на трудные цели и отдаленные перспективы успешности планируемой стратегии, осознания зависимости результата от своего социально-психологического и профессионального ресурсного капитала, а также инициативности.

Высокий уровень исследуемых индикаторов поддерживает стремление студента к выбору адекватных способов и путей формирования доминантных признаков социально-психологического капитала и карьерного планирования. Студентов данной группы можно отнести к числу высокоресурсных людей, которые имеют хороший лидерский потенциал и, вероятно, достигнут определенных высот на карьерной лестнице. Данные показатели отражают позитивную репрезентацию образа будущего человека труда, который стремится быть успешным, работать на результат, самореализовываться, имеет достаточно четкое представление о своем будущем вплоть до долгосрочной перспективы. У таких людей образ будущего страны также представлен в положительном ключе.

Студент со средним уровнем выраженности маркеров планирования карьеры в процессе профессиональной подготовки имеет отличительные индивидуальнопсихологические особенности социально-психологического капитала личности: потребность в самоуважении, подкрепленную значимостью поощрений, положительных оценок со стороны других, статуса, выбора престижных профессий и др. Студенты считают важным присутствие положительного микроклимата в группе, проявление гуманных отношений, предварения конфликтных ситуаций или безболезненного их разрешения.

Студенты группы со средним уровнем показателей могут прогнозировать, анализировать противоречия во взаимоотношениях, ориентироваться в ситуациях (.45.1). Они испытывают напряженность и чувствительность, характеризующую их состояние психосоматики, в средней мере проявляют интерес к жизни (.59.7), настроенность на лучшее в будущем (.69.2), неустойчивые установки на труд (.27), на альтруизм (.12), на эгоизм $\left(.16^{*}\right)$ в ориентации на карьеру. Не придают большого смысла значимости и оценке уровня достигнутых результатов (.29), оценке своего потенциала (.39.1), намеченного уровня мобилизации усилий (.31). Данная группа студентов обладает с целом позитивным взглядом в будущее и репрезентует его скорее как нейтральноположительное. Образ будущего четко не выстроен, имеется относительно однозначное видение своего будущего на ближайшую и среднюю перспективу (до 3-5 лет).

Студенты с низким уровнем показателей (в диапазоне от .52 до .21), игнорируют выбор карьеры в системе «человек-природа», не имеют необходимых навыков управления средой, целями в жизни, низко оценивают способность справляться с повседневными делами, не проявляют готовности улучшить свое качество жизни, переживают 
свое социально-психологическое неблагополучие. Не умеют адекватно оценить свой потенциал, жизненные перспективы, теряются в новых ситуациях, слабо осознают смысл профессионального становления. Установка на процесс блокирует эффективную включенность в процесс планирования карьеры, отсутствует ориентация на власть как желание оказывать влияние на других, низкая установка на труд становится значимым барьером планирования карьеры.

Для студентов с низким уровнем характерна несформированность способности принятия решений, целеполагания, планирования, умение продумывать последовательность своих действий, формировать программу действий, принимать решение перехода от плана к действиям, создавать результат-модель средств достижения цели (в диапазоне от 3б. до 6б.). Студенты не имеют навыка коррекции реальных ситуаций и своих социально-психологических особенностей. Следует отметить, что мотивационный комплекс не оптимален, превалирует внешне отрицательная мотивация, что влечет за собой эмоциональную нестабильность, переживания, приводит к уходу от решения, неудовлетворенности.

По параметрам жизнестойкости у студентов данной группы выявлена высокая зависимость от социально-экономической ситуации в обществе, несформированность умений регуляторной активности в социально-психологической сфере, низкий контроль над ситуацией, отсутствует готовность рисковать, предпринимать активные действия. Имеет место низкий уровень удовлетворенности повседневной жизнью, согласованность между поставленными и достигнутыми целями. Респонденты не стремятся и не проявляют волевого усилия, не обладают готовностью конкурировать и быстро переключаются на новые, более знакомые и легкие виды деятельности. Студенты данной группы являются низкоресурсными. Образ будущего у них практически не сформирован.

Учитывая полученные результаты, была подтверждена гипотеза о том, что имеется существенная связь между карьерным планированием, социально-психологическим капиталом и карьерной адаптивностью. «Кроме того, адаптивность карьеры оказывает положительное влияние на профессиональную компетентность. В этом отношении адаптивность карьеры опосредует отношения между психологическим капиталом и профессиональной компетенцией» [25]. На основании обобщенных выше эмпирических данных мы предлагаем рассмотреть содержание и адаптированные формы работы вуза, как возможный вариант формирования компетенции карьерного планирования, реализуемый одновременно с развитием и/или наращиванием социальнопсихологического капитала личности.

В условиях динамично меняющейся социально-образовательной среды повышается роль психолого-педагогического изучения, разработки обоснованного управления студентом процесса планирования образа будущего своей карьеры. Социальнопсихологическая служба и педагогический коллектив вуза решают задачу поддержки студенческой молодежи с целью организации сотрудничества студента, вузовского сообщества и будущих работодателей. Программы службы социально-психологического сопровождения студентов направлены на приобретение навыков эффективного взаимодействия, развития мобильности, активной жизненной позиции, стратегий профессионально-личностного роста, психологического благополучия в трудовой деятельности и жизни [11]. Сотрудники службы в своих рекомендациях предлагают акцентировать внимание администрации вуза на содержании работы формирования студентом детального выстраивания репрезентации будущего, управления временем и личным ресурсным капиталом при планировании карьеры. Иными словами, предлагаемая нами стра- 
тегия вуза по формированию компетенции карьерного планирования может послужить источником позитивных изменений в репрезентации профессионального и личного будущего студента.

Первоначально вуз не может оказать значительное влияние на карьерное планирование студента (профориентационная и агитационная работа в школах, ссузах; беседы и консультации в приемных комиссиях). Когда абитуриент осуществил выбор профессии и был зачислен в ряды студентов вуза на соответствующее направление, он еще не осознал в полной мере требований образовательного процесса, соблюдения учебной дисциплины, необходимости самоорганизации во времени, напряженности учебного труда, профессиональной подготовки и др. У него недостаточно знаний своих индивидуально-психологических возможностей, своего призвания. На данном этапе вчерашние выпускники школ, которых большинство, не в полной мере могут адекватно оценить перспективы будущей профессиональной деятельности или масштаб реализации своего потенциала.

Реализация стратегии вуза по формированию планирования карьеры студентом начинается в начале учебного года на первом курсе. Данный этап карьерного планирования выстраивается на продуманном плане работы, рассчитанном на весь период обучения студента в стенах учебного заведения. Как показывают исследования, у большинства студентов первого курса первоначально нет четко выстроенных профессиональных намерений и представлений о будущей профессиональной деятельности, кроме понимания в какой сфере они хотели бы самореализоваться. В начальный период получения профессионального образования, преподаватель передает студентам в рамках своей учебной дисциплины представления об их будущей деятельности. Кураторы групп, преподаватели-методисты, заинтересованные в развитии и становлении молодых кадров, знакомят их с особенностями профессиональной подготовки. Студент начинает осознавать, в какое профессиональное сообщество он попадет после обучения, какой спектр направлений деятельности и должности в соответствующей сфере будут ему доступны после окончания вуза, какие знания, навыки, soft skills и компетенции карьерного планирования он получит и сможет применить в профессиональной деятельности, какую информацию, полезные контакты приобретет в лице сокурсников, преподавателей и потенциальных/реальных работодателей. Это все органично вписывается в базовый компонент карьерного планирования.

Далее студенты закрепляют осознанный выбор профессии, у них расширяется диапазон самопознания, видение перспектив самореализации, использование и дальнейшее формирование ресурса социально-психологического капитала, желание формировать профессиональные компетенции, в том числе карьерного планирования. Введение в образовательный процесс модулей и отдельных дисциплин, связанных с социально-профессиональным самоопределением (например, «Введение в инженерную деятельность», «Профессиональное самоопределение и карьера», «Мотивация и карьерная навигация») позволяет студентам начать адекватно планировать будущую успешную карьеру. Содержание подобных дисциплин формирует социально-психологические, общекультурные компетенции и soft skills. Студенты усваивают историкотеоретические знания отечественных и зарубежных авторов о профессиональном самоопределении, самореализации личности, понятии карьеры, развитии рынка труда, спроса на профессии, формирования представлений о технологиях планирования профессиональной карьеры. Практические и семинарские занятия помогают студентам ориентироваться на рынке труда с учетом целей личной и профессиональной самореализации, проявлять готовность включаться и успешно адаптироваться в социально- 
профессиональной жизни. Часть занятий имеют практико-ориентированный характер, где студенты учатся презентовать себя работодателю, включать свои ресурсы лидерских и предпринимательских качеств, навыки командной работы.

Содержание занятий включает диагностику, материалы, относящиеся к самопознанию, самосовершенствованию, мотивации к успеху, планированию своей профессиональной карьеры. Студенты с низким уровнем показателей приобретают умение преодолевать неуверенность в своих силах, видеть реальные перспективы карьерной самореализации и достижения благополучия, корректировать установку на труд и адекватно оценивать собственный потенциал. Для студентов, вошедших в группу со средними показателями, участие в мероприятиях и занятиях по планированию карьерного вектора позволяет снизить чувство напряженности, скорректировать установку на труд и ориентацию на карьеру в положительном ключе. Студенты с высокими показателями закрепляют свою целеустремленность и могут более детально выстроить репрезентацию своего будущего.

Часть занятий ориентирована на формирование необходимых навыков повышения социальной компетентности, адаптации, профориентации и др. В занятия включаются упражнения, рекомендации, правила, которые помогут студенту презентовать себя, развивать коммуникативные умения, умение выбора наиболее эффективного способа выхода из конфликтной ситуации, методы и техники подготовки себя к предстоящему собеседованию с работодателем, правильному составлению резюме, успешной адаптации на новом рабочем месте и др.

Центр содействия трудоустройству и развитию карьеры, Центр «Карьера», Отдел профориентации, дополнительного образования и развития карьеры при вузах непосредственно включаются как в образовательную деятельность наряду с педагогами предметных дисциплин, так и во внеучебную работу для проведения индивидуальных занятий-тренингов по составлению проектов профессиональной карьеры. Кроме того, вузом поддерживается активность студента, направленная на овладение профессиональными компетенциями, управление позитивным эмоционально-личностным состоянием, желанием реализовать себя как будущего специалиста, заниматься поиском подходящего вида труда и т. д. Организуется взаимодействие, общение со студентами старших курсов, преподавателями, руководителями производственных практик, работодателями, обмен имеющимся трудовым опытом и трудовое наставничество.

Одна из форм работы формирования компетенции карьерного планирования, предлагаемая к внедрению в образовательный процесс вуза, была апробирована нами совместно с преподавателями психологии и студентами второго курса. Первоначально планирование карьеры предполагает необходимость студенту раскрыть возможности своего социально-психологического капитала, определить направления развития уже осознаваемого потенциала, цель и стратегию своей деятельности, что повышает эффективность планирования будущей карьеры.

Преподаватель подводит студента к пониманию внутриличностных изменений, последовательности своего профессионального развития, представлений о перспективах трудовой деятельности, анализа своих возможностей в соотношении с требованиями будущей профессии. Визуализация данного понимания реализуется в предлагаемой преподавателем и заполняемой студентом ментальной карте (mind map). Тем самым создается основа формирования социально-профессионального самоопределения личности.

Организуя проектную деятельность, преподаватель использует самооценку в форме анализа студентом имеющегося собственного ресурса социально-психологического 
капитала, возможностей, отдельных умений, навыков и технику «Пирамида логических уровней Дилтса». Преподаватель поддерживает у студента ощущение продвижения по уровням: окружение, поведение, способности, убеждение-ценность, личностное своеобразие, миссия, которые составляют пирамиду уровней.

Решением следующей задачи «Определение параметров и мотивации развития профессиональной карьеры» осуществлялся «спуск с пирамиды», что позволяет студенту проанализировать упущенные возможности, планировать внесение изменений, коррекции параметров того вида деятельности, где и как студент склонен проектировать будущую карьеру.

Далее преподаватель использует технику SMART-целеполагание по определению и разграничению целей профессионального развития на краткосрочные и долгосрочные.

Используя прием геймификации на занятии по теме «Развитие плана служебного роста», преподаватель ориентирует студента на освоенный путь, оценку актуальных и желаемых качеств. Другими словами, студент определяет с использованием идеографического подхода, какими социально-личностными характеристиками он обладает в полной мере, какие профессиональные характеристики необходимо иметь, а какие надо приобрести и развить для предполагаемой карьеры. Это необходимо, поскольку при использовании техники управляемого воображения выстраивается карьерный вектор, который впоследствии служит предметом анализа в карьерном планировании [26]. Кроме того, моделируется ситуация с позитивным и негативным карьерными шоками, т. к. известно, что они «играют важную роль в раннем развитии карьеры молодых специалистов в сочетании с профессиональными компетенциями и карьерным успехом» [27].

На этапе контроля достигнутых целей преподаватель совместно со студентами анализирует краткосрочные цели после производственной практики в конце второго курса, что позволяет оценить степень готовности студента к будущей профессиональной деятельности, внести необходимые коррективы в проект будущей карьеры и ментальную карту, определить спектр направлений для дальнейшего развития. Использование такой технологии планирования карьеры построено с учетом использования наличного социально-психологического капитала студента, осознающего стратегию, направление, готовность своего профессионального развития в выбранной профессии, желание развивать свой капитал в будущем.

Эффективность и результативность деятельности вуза в части карьерного планирования студентом определяется тем, насколько будущий выпускник вуза на заключительных этапах обучения социально и профессионально самоопределился, успешно овладел профессиональными компетенциями, самоидентифицировался в профессии и готов к реализации спланированной в вузе профессиональной карьеры, имеет ли он запасные копинг-стратегий на случай возможных карьерных шоков [27], рисков и неудач в профессиональной сфере, готов ли к переобучению или повышению квалификации. Предвосхищая возможные трудности, которые могут возникнуть у студентов на этапе завершения профессиональной подготовки, вуз создает условия для оказания целенаправленной помощи студентам в социально-профессиональном самоопределении совместной деятельностью преподавателей, методистов и сотрудников Центра содействия трудоустройству и развитию карьеры, центра «Карьера», отдела профориентации, дополнительного образования и развития карьеры. В реализацию спланированного студентом карьерного вектора вуз привлекает работодателей. 
В этом направлении показателен совместный опыт работы вуза и учебного консультационно-методического центра профориентации и содействия трудоустройству выпускников «Карьера» компании «РУСАЛ» (Новокузнецк). Работодатель, отмечая пробелы современной системы профобразования в рамках программы «Новое поколение», решает задачу подготовки своего специалиста с набором необходимых компетенций. Интегрированные soft skills важны для работодателя так же, как и академические знания будущего работника, чем определяется ценность карьерного и социального лифта сотрудника [28].

Региональный центр подготовки персонала «ЕВРАЗ-СИБИРЬ» (Новокузнецк) также включается в совместную работу с вузом. Проводя профориентационную работу среди молодежи, центр поддерживает реализацию профессиональных, социальнопсихологических и педагогических компонентов, актуальных в работе компании и подготовки рабочей смены. Интересом пользуются организуемые центром мероприятия, тренинги личностного и профессионального совершенствования, где решаются проблемы психологии безопасного, коммуникативного, управленческого поведения, командообразования, профориентационной направленности школьников, студентов.

Таким образом, формирование компетенции планирования профессионального будущего соотносится с социально-психологической готовностью индивида как одной из социально-профессиональных установок личности [29, 30]. Формирование компетенции планирования карьеры студентов проходит в специально организованных условиях профессиональной подготовки, зависит как от вуза, так и от имеющегося ресурса социально-психологического капитала каждого отдельного индивида. Планирование карьеры связано с рефлексией человека, пониманием, что будущие результаты формирует текущая деятельность [31], в связи с чем, успешность обучения в вузе во многом детерминирует формирование социально-профессионального и личностного капитала. Исследователями указывается, что карьерный рост доступен высокоресурсному человеку, низкоресурсный индивид мирится с несбывшимися ожиданиями, недостаточным уровнем образования, неудовлетворенностью рабочим местом, профессией и др. [32]. Задача вуза помочь низкоресурсному студенту в направлении перехода в группу с достаточным ресурсом, а студенту с достаточным ресурсом и высокоресурсным студенту четко выстроить вектор карьеры и образ будущего.

Реально оценивая сложившуюся социально-экономическую ситуацию, вуз первоначально ориентирован на поддержку программ создания оптимальных условий самопознания и развития студентом своего ресурса, оценки адекватных представлений реальных и потенциальных возможностей профессионального становления, материальных запросов, востребованности на рынке труда. Целенаправленная работа осуществляется в отношении развития у студентов профессиональной мотивации, мобильности, компетентности, предвидения потребности рынка труда, возможных рисков на рынке труда в области своей профессиональной деятельности, конкурентоспособности, социализации, адаптации в обществе, содействия в планировании их будущего профессионального роста, успешности, социально-психологического и профессионального благополучия.

Результативной будет работа, проводимая вузом совместно с базовыми предприятиями региона и/или страны, чтобы студенты имели возможность не только пилотного приложения своих знаний в рамках практики, но и могли увидеть реальные примеры реализации спланированного роста по карьерному вектору. Активная включенность студента в разнообразные мероприятия вуза и работодателей позволят ему определить и оценить свои возможности в направлении профессиональных компетенций, увидеть 
потенциальные пути их реализации, а как результат - спланировать свою карьеру и выстроить положительную репрезентацию образа своего будущего.

Исследование выполнено при финансовой поддержке РФФИ и АНО ЭИСИ в рамках научного проекта № 19-011-31182.

\section{СПИСОК ЛИТЕРАТУРЫ}

1. Лангер С. Философия в новом ключе: Исследование символики разума, ритуала и искусства. - М.: Республика, 2000. - 287 с.

2. Разгоняева Е.В. Личностная обусловленность процесса построения образа будущего: дис. ... канд. психол. наук. - Барнаул, 2004. - 175 с.

3. Нюттен Ж. Мотивация, действие и перспектива будущего - М.: Смысл, 2004. - 608 с.

4. Концепция долгосрочного социально-экономического развития Российской Федерации на период до 2020 года: распоряжение правительства от 17.11. 2008 № 1662-р (ред. 28.09.2018). // URL: http://www.consultant.ru/document/cons_doc_LAW_82134/28c7f9e359e8af09d7244d8033c66928fa27e527/ (дата обращения 30.03.2019).

5. Relationships Between Optimism, Educational Environment, Career Adaptability and Career Motivation in Nursing Undergraduates: a Cross-Sectional Study / W. Fang, Y. Zhang, J. Mei, X. Chai, X. Fan // Nurse Education Today. - 2018. - V. 68. - P. 33-39. DOI: 10.1016/j.nedt.2018.05.02.

6. Maree J.G. Group Career Construction Counseling: A Mixed-Methods Intervention Study with High School Students // Career Development Quarterly. - 2019. - V. 67. - Iss. 1. - P. 47-61. DOI: 10.1002/cdq.12162.

7. Park J.S.-Y. Mediatizing Neoliberalism: the Discursive Construction of Education's 'Future' // Language and Intercultural Communication. - 2018. - V. 18. - Iss. 5. - P. 478-489. DOI: 10.1080/14708477.2018.1501843.

8. Райзберг Б.А., Лозовский Л.Ш., Стародубцева Е.Б. Современный экономический словарь. - М.: Инфра-М, 1999. - 479 с.

9. Деркач А.А., Орбан Л.Э. Акмеологические основы становления психологической и профессиональной зрелости личности. - М.: Изд-во РАГС, 1995. - 208 с.

10. Зеер Э.Ф. Профессионально-образовательное пространство личности. - Екатеринбург: Изд-во РГППУ, 2002. - $122 \mathrm{c}$.

11. Наука и социум: педагогика и психология (становление, ценности и приоритеты): монография / под общ. ред. О.И. Кирикова. - Воронеж: Изд-во ВГПУ, 2012. - 196 с.

12. Son S. The More Reflective, the More Career-Adaptable: a Two-Wave Mediation and Moderation Analysis // Journal of Vocational Behavior. - 2018. - V. 109. - P. 44-53.

13. Hartung P.J., Santilli S. My Career Story: Description and Initial Validity Evidence // Journal of Career Assessment. - Vol. 26. - Iss. 2. - P. 308-321. DOI: 10.1177/1069072717692980.

14. Студенты Кузбасса предпочитают деньги карьере. URL: http://nk-tv.com/132371.html (дата обращения 17.10.2018).

15. Каждый четвертый молодой специалист Кемеровской области видит себя в будущем директором компании // Бизнес-портал Кузбасса. Деловые новости от 18 сентября 2015 г. URL: https://www.avantpartner.ru/news/9133.html (дата обращения 20.12.2018).

16. Рикель А.М., Тихомандрицкая О.А. Особенности переживания успешности «вертикальной» и «горизонтальной» карьеры сотрудниками организаций // Психологические исследования. - 2013. - Т. 6. № 28. URL: http://psystudy.com/index.php/num/2013v6n28/810-rickel28.html (дата обращения 03.08.2017).

17. Татарко А.Н. Социально-психологический капитал личности в поликультурном обществе: структура и динамика // Общественные науки и современность. - 2014. - № 1. - С. 50-64.

18. Татарко А.Н. Социально-психологический капитал личности в поликультурном обществе. - М.: Институт психологии РАН, 2014. - 384 с.

19. Татарко А.Н. Социально-психологический капитал личности как фактор успеха в открытии нового бизнеса // Психология. Журнал Высшей школы экономики. - 2013. - Т. 10. - № 4. - С. 80-98.

20. Татарко А.Н., Лебедева Н.М. Социальный капитал: теория и психологические исследования: монография. - М.: Изд-во РУДН, 2009. - 233 с.

21. Шихирев П.Н. Природа социального капитала: социально-психологический подход // Общественные науки и современность. - 2003. - № 2. - С. 18-19. 
22. Представления россиян о будущем страны через 20 лет. URL: https://fom.ru/Budushchee/13169 (дата обращения 13.04.2019).

23. Джанерьян С.Т. Системный подход к изучению профессиональной Я-концепции // Вестник Оренбургского государственного университета. Приложение «Гуманитарные науки». - 2005. - № 4. C. $162-169$.

24. Рикель А.М. Профессиональная Я-концепция и профессиональная идентичность в структуре самосознания личности. Ч. 1 // Психологические исследования: электронный научный журнал. - 2011. № 2 (16). URL: http://psystudy.ru/num/2011n2-16/457-rikel16 (дата обращения 09.06.2017).

25. Safavi H.P., Bouzari M. The Association of Psychological Capital, Career Adaptability and Career Competency Among Hotel Frontline Employees // Tourism Management Perspectives. - 2019. - V. 30. P. 65-74. DOI: 10.1016/j.tmp.2019.02.001.

26. Stoltz K.B., Apodaca M., Mazahreh L.G. Extending the Narrative Process: Guided Imagery in Career Construction Counselin // Career Development Quarterly. - 2018. - V. 66. - Iss. 3. - P. 259-268. DOI: 10.1002/cdq. 12147.

27. Building a Sustainable Start: the Role of Career Competencies, Career Success, and Career Shocks in Young Professionals' Employability / R. Blokker, J. Akkermans, M. Tims, P. Jansen, S. Khapova // Journal of Vocational Behavior. - 2019. - V. 112. - P. 172-184. DOI: 10.1016/j.jvb.2019.02.013

28. РУСАЛ - это не просто работа, это карьера. URL: http://kuzpress.ru/society/26-05-2017/52938.html (дата обращения 12.04.2019).

29. The Determinants of Human Wellbeing in Professional Activities / T. Konyukhova, E. Konyukhova, V., Kashpur J. Lokotosh // The European Proceedings of Social \& Behavioural Sciences (EpSBS). - 2017. V. XIX: Proc. of the III International Scientific Symposium on Lifelong Wellbeing in the World (WELLSO 2016). - Tomsk, Russia, 11-16 September 2016. - P. 344-348. DOI: 10.15405/epsbs.2017.01.46.

30. Goal-Setting in the Contemporary Educational Environment / T. Konyukhova, E. Konyukhova, Z., Zavyalova E. Suhushina, O. Osokina, O. Sichevskaya // 11th International Technology, Education and Development Conference (INTED2017). - Valencia, Spain, 6-8 March, 2017. - Valencia: IATED, 2017. P. 2044-2049. DOI: 10.21125/inted.2017.0610.

31. Кастельс М. Информационная эпоха: экономика, общество и культура. - М.: ГУ ВШЭ, 2000. - 608 с. URL: http://www.gumer.info/bibliotek_Buks/Polit/kastel/index.php (дата обращения 09.06.2017).

32. Посухова О.Ю. Конструирование профессиональной карьеры в политической сфере российского общества // Власть. - 2015. - Т. 23. - № 9. - С. 21-26.

Поступила 20.04.2019 2. 
UDC 005.966:101.1:316.444.32

\title{
FORMATION OF CAREER CONSTRUCTION COMPETENCE IN THE FUTURE VISION REPRESENTATION
}

\author{
Tatiana V. Konyukhova ${ }^{1}$, \\ konykhova@tpu.ru \\ Ekaterina T. Konyukhova ${ }^{2}$, \\ konjuhova50@mail.ru \\ Mark V. Goncharenko1, \\ markgon73@tpu.ru
}

${ }^{1}$ National Research Tomsk Polytechnic University, 30, Lenin Avenue, Tomsk, 634050, Russia

2 Kemerovo State University in Novokyznetsk, 23, Tsiolkovsky street, Novokuznetsk, 654041, Russia

Tatiana V. Konyukhova, Cand. Sc., associate professor, National Research Tomsk Polytechnic University.

Ekaterina T. Konyukhova, Cand. Sc., associate professor, Kemerovo State University in Novokyznetsk.

Mark V. Goncharenko, Dr. Sc., associate professor, National Research Tomsk Polytechnic University.

Based upon the theory of career construction we highlight problematic related to career planning. It allows personalities to stimulate themselves to construct and implement successful social and labor relations. Career construction is one of the aspects of well-being, creation the vision of the future and its representation. Career planning is formed taking into account the resource potential of the social and psychological capital of the student's personality. Career competence is built on the ability of a person to recognise the possibilities of his(her) career capabilities in order to use them for career advancement and ability to overcome obstacles and difficulties in order to optimize career vector. The aim of the study is to give recommendations for forming students' professional career planning competence in the university educational space. Methods: comparative and statistical analysis of empirical data obtained from a diagnostic study. The diagnostic toolkit included a method for ranking the signs of a career concept; questionnaires: life Satisfaction Index (adaptation by N.V. Panina); differential diagnostic questionnaire (DDQ) (E.A. Klimov); techniques: satisfaction of basic needs (A. Maslow); socio-psychological attitudes (O.F. Potemkin); resilience at work (C. Maddi); scale of subjective well-being; scale of psychological well-being (C. Riff); ability to self-government (N.M. Peisakhov); professional motivation (K. Zamfir in the modification of A. Rean). Processing was carried out using the SPSS 22.0 statistical software package for social sciences. Results. The concept of the competence of career planning is formulated and its role in the vision of the future is described. The authors have carried out the research of structural components of forming career construction by future specialists. Based on the data the socio-psychological portraits of different students groups were drawn up. The recommendation of possible strategy of forming up a university's work was described. We suppose that its implementation could help to format of a students' career planning competence through the development of parameters of a students' social and personal characteristics and his(her) social and psychological capital.

Key words: Career, competence, career planning, career construction, representation, vision of the future, social and psychological capital.

The reported study was funded by RFBR and EISR according to the research project no. 19-011-31182. 


\section{REFERENCES}

1. Langer S. Filosofiya v novom klyuche: Issledovanie simvoliki razuma, rituala i iskusstva [Philosophy in a new vein: study of the symbolism of reason, ritual and art]. Moscow, Respublika Publ., 2000. 287 p.

2. Razgonyaeva E.V. Lichnostnaya obuslovlennost protsessa postroeniya obraza budushchego. Dis. Kand. nauk [Personal conditionality of the process of building the image of the future. Cand. Diss.]. Barnaul, 2004. $175 \mathrm{p}$

3. Nyutten Zh. Motivatsiya, deystvie i perspektiva budushchego [Motivation, action and future outlook]. Moscow, Smysl Publ., 2004. 608 p.

4. Kontseptsiya dolgosrochnogo sotsialno-ekonomicheskogo razvitiya Rossiyskoy Federatsii na period do 2020 goda [Government Decree of 17.11. 2008 no. 1662-p (ed. 09/28/2018 On the Concept of long-term socio-economic development of the Russian Federation for the period up to 2020]. Rasporyazhenie pravitelstva ot 17.11.2008 no. 1662-r (red. 28.09.2018). Available at: http://www.consultant.ru/document/ cons_doc_LAW_82134/28c7f9e359e8af09d7244d8033c66928fa27e527/ (accessed 30 March 2019).

5. Fang W., Zhang Y., Mei J., Chai X., Fan X. Relationships Between Optimism, Educational Environment, Career Adaptability and Career Motivation in Nursing Undergraduates: a Cross-Sectional Study. Nurse Education Today, 2018, vol. 68, pp. 33-39. DOI: 10.1016/j.nedt.2018.05.02.

6. Maree J.G. Group Career Construction Counseling: a Mixed-Methods Intervention Study with High School Students. Career Development Quarterly, 2019, vol. 67, Iss. 1, pp. 47-61. DOI: 10.1002/cdq.12162.

7. Park J.S.-Y. Mediatizing Neoliberalism: the Discursive Construction of Education's 'Future'. Language and Intercultural Communication, 2018, vol. 18, Iss. 5, pp. 478-489. DOI: 10.1080/14708477.2018.1501843.

8. Rayzberg B.A., Lozovskiy L.Sh., Starodubtseva E.B. Sovremenny ekonomicheskiy slovar [Modern Economic Dictionary]. Moscow, Infra-M Publ., 1999. 479 p.

9. Derkach A.A., Orban L.E. Akmeologicheskie osnovy stanovleniya psikhologicheskoy i professionalnoy zrelosti lichnosti [Acmeological basis of formation of psychological and professional maturity of the individual]. Moscow, RAGS Publ., 1995. 208 p.

10. Zeer E.F. Professionalno-obrazovatelnoe prostranstvo lichnosti [Personality Vocational Area]. Ekaterinburg, RGPPU Publ., 2002. 122 p.

11. Nauka i socium: pedagogika i psihologija (stanovlenie, cennosti i prioritety) [Science and society: pedagogy and psychology (formation, values and priorities)]. By ed. O.I. Kirikova.Voronezh, VGPU, 2012. 196 p. Son S. The More Reflective, the More Career-Adaptable: a Two-Wave Mediation and Moderation Analysis. Journal of Vocational Behavior, 2018, vol. 109, pp. 44-53.

12. Son S. The More Reflective, the More Career-Adaptable: a Two-Wave Mediation and Moderation Analysis. Journal of Vocational Behavior, 2018, vol. 109, pp. 44-53.

13. Hartung P.J., Santilli S. My Career Story: Description and Initial Validity Evidence. Journal of Career Assessment, vol. 26, Iss. 2, pp. 308-321. DOI: 10.1177/1069072717692980.

14. Studenty Kuzbassa predpochitayut dengi karere [Kuzbass Students Prefer Money to Career]. Available at: http://nk-tv.com/132371.html (accessed 17 October 2018).

15. Kazhdy chetverty molodoy spetsialist Kemerovskoy oblasti vidit sebya v budushchem direktorom kompanii [Every fourth young specialist of the Kemerovo region sees himself as a future director of the company]. Biznes-portal Kuzbassa. Delovyye novosti ot 18 sentyabrya $2015 \mathrm{~g}$. Available at: https://www.avantpartner.ru/news/9133.html (accessed 20 December 2018).

16. Rikel A.M., Tikhomandritskaya O.A. Osobennosti perezhivaniya uspeshnosti «vertikalnoy» i «gorizontalnoy» karery sotrudnikami organizatsiy [Peculiarities of experiencing the success of a «vertical» and «horizontal» career by employees of organizations]. Psihologicheskie issledovanija, 2013, Vol. 6, no. 28. Available at: http://psystudy.com/index.php/num/2013v6n28/810-rickel28.html (accessed 3 August 2017).

17. Tatarko A.N. Socialno-psikhologicheskiy kapital lichnosti v polikulturnom obshchestve: struktura i dinamika [Socio-psychological capital of the individual in a multicultural society: structure and dynamics]. Obshchestvennye nauki i sovremennost, 2014, no. 1. pp. 50-64.

18. Tatarko A.N. Sotsialno-psikhologicheskiy kapital lichnosti v polikulturnom obshchestve [Sociopsychological capital of the individual in a multicultural society]. Moscow, Psychology Institute RAS Publ., 2014. $384 \mathrm{p}$.

19. Tatarko A.N. Sotsialno-psikhologicheskiy kapital lichnosti kak faktor uspekha v otkrytii novogo biznesa [Socio-psychological capital of the individual as a success factor in opening a new business magazine]. Psihologiya. Zhurnal Vysshey shkoly ekonomiki, 2013, vol. 10, no. 4, pp. 80-98.

20. Tatarko A.N., Lebedeva N.M. Sotsialny kapital: teoriya i psikhologicheskie issledovanya [Social capital: theory and psychological research]. Moscow, RUDN Publ., 2009. 233 p. 
21. Shikhirev P.N. Priroda sotsialnogo kapitala: sotsialno-psikhologicheskiy podkhod [The nature of social capital: a socio-psychological approach]. Obshchestvennye nauki i sovremennost, 2003, no. 2, pp. 18-19.

22. Predstavleniya rossiyan o budushchem strany cherez 20 let [Representations of Russians about the future of the country in 20 years]. Available at: https://fom.ru/Budushchee/13169 (accessed 13 April 2019).

23. Dzhaneryan S.T. Sistemny podkhod k izucheniu professionalnoy Ya-konceptsii [System approach to the study of professional self-concept]. Vestnik Orenburgskogo gosudarstvennogo universiteta. Prilozhenie «Gumanitarnye nauki», 2005, no. 4, pp. 162-169.

24. Rikel A.M. Professionalnaya Ya-kontseptsiya i professionalnaya identichnost v strukture samosoznaniya lichnosti. Ch. 1 [Professional self-concept and professional identity in the structure of self-identity. P. 1]. Psikhologicheskie issledovaniya: elektronny nauchny zhurnal, 2011, no. 2 (16). Available at: psystudy.ru/num/2011n2-16/457-rikel16 (accessed 9 June 2017).

25. Safavi H.P., Bouzari M. The Association of Psychological Capital, Career Adaptability and Career Competency Among Hotel Frontline Employees. Tourism Management Perspectives, 2019, vol. 30, pp. 65-74. DOI: $10.1016 /$ j.tmp.2019.02.001.

26. Stoltz K.B., Apodaca M., Mazahreh L.G. Extending the Narrative Process: Guided Imagery in Career Construction Counselin. Career Development Quarterly, 2018, vol. 66, Iss. 3, pp. 259-268. DOI: 10.1002/cdq. 12147 .

27. Blokker R., Akkermans J., Tims M., Jansen P., Khapova S. Building a Sustainable Start: the Role of Career Competencies, Career Success, and Career Shocks in Young Professionals' Employability. Journal of Vocational Behavior, 2019, vol. 112, pp. 172-184. DOI: 10.1016/j.jvb.2019.02.013

28. RUSAL - eto ne prosto rabota, eto karera [RUSAL is not just a job; it is a career]. Available at: http://kuzpress.ru/society/26-05-2017/52938.html (accessed 12 April 2019).

29. Konyukhova T., Konyukhova E., Kashpur V., Lokotosh J. The Determinants of Human Wellbeing in Professional Activities. The European Proceedings of Social \& Behavioural Sciences (EpSBS). 2017. Vol. XIX. Proc. of the III International Scientific Symposium on Lifelong Wellbeing in the World (WELLSO 2016). Tomsk, Russia, 11-16 September 2016. pp. 344-348. DOI: 10.15405/epsbs.2017.01.46.

30. Konyukhova T., Konyukhova E., Zavyalova Z., Suhushina E., Osokina O., Sichevskaya O. Goal-Setting in the Contemporary Educational Environment. $11^{\text {th }}$ International Technology, Education and Development Conference (INTED2017). Valencia, Spain, 6-8 March, 2017. Valencia, IATED, 2017. pp. 2044-2049. DOI: 10.21125 /inted.2017.0610.

31. Kastels M. Informatsionnaya epokha: ekonomika, obshchestvo i kultura [Information Age: Economics, Society and Culture]. Moscow, GU VShE Publ., 2000. 608 p. Available at: http://www.gumer.info/bibliotek_Buks/Polit/kastel/index.php (accessed: 09.06.2017)

32. Posukhova O.Yu. Konstruirovanie professionalnoy karery v politicheskoy sfere rossiyskogo obshchestva [Designing a professional career in the political sphere of Russian society]. Vlast, 2015, vol. 23, no. 9, pp. 21-26.

Received: 20 April 2019. 